\title{
Forme ale evaziunii în poezia recentă a Anei Blandiana
}

\author{
Drd. KIȚU Daniel \\ Universitatea „Dunărea de Jos” din Galați
}

\begin{abstract}
Summary: This study starts from an essential feature of Anna Blandiana's lyrics, which is often mentioned by literary criticism, namely the dualism of the structure of the poetic message. On the one hand, there is the real, with its inherent avatars that strike the spiritual structure of the lyrical ego. On the other hand, the are the forms of evasion that the poet imagines at different levels of her poetics: meditation on the destiny of writing, creator's place in the world, discrepancy between the vulgar, defiling mundane and the aspiration to purification through the creative affection. While the exterioriry in Ana Blandiana's poetry often involves limitation, suffocation of the spirit, claustromorphic obsession, the ego's evasionism expresses temptation to illimitatus, eternity through creation and propensity to various forms of intimacy. In order to investigate these ways of evasion proposed by Ana Blandiana, we will take into account the last three volumes published by the poet during 2008 and 2016: "Reflux of Sign"s, "My Homeland A4" and "Hourless Clock".
\end{abstract}

Keywords: evasion, desecration, dualism, lyric, limitation.

I. Preambul

Poezia din ultimele trei volume publicate de Ana Blandiana și mai cu seamă cea din cartea care a văzut lumina tiparului în 2016, Orologiul fără ore, definește o permanentă pendulare între ontologic și scriptural.

Sunt poemele unui ontos grevat de o stare de urgență a umanului, pe care poeta o resimte din ce în ce mai acut. Se remarcă, astfel, tot mai evident, „extenuarea grea, catifelată a simțurilor pe care doar cuvintele le mai pot înviora." 217

În lumea poetei este relevată amprenta unei bipolarități ${ }^{218}$ vizibile. De aici derivă dualitatea structurală a viziunii poetice a Anei Blandiana, cea care

${ }^{217}$ Irina Petraș, Eroziuni secundare, în rev. „Viața Românească”, București, nr. 9/ 2016, p. 1.

${ }^{218}$ Monica Patriche, Credința ca unica șansă în viziunea poetei Ana Blandiana, în rev. „Ziarul Lumina”, 04.11/ 2016, p. 1.: „Lumea Anei Blandiana din Patria mea A4 poartă amprenta 
plasează într-o relație de contrapondere mundanul imund și teritoriul evanescent fie al inspirației poetice, al Logosului purificator sau cel al oniricului, care-a sedus-o deseori pe scriitoare, nu numai pe autoarea de versuri.

În mod firesc vine tentația eului poetic de-a se deroba de real, de a-și aroga un teritoriu purificat de miasmele unei lumi care-o alienează. Manifestarea lirică a acestei tentații este evaziunea, dorința de-a se metamorfoza poetic în alte dimensiuni care o eliberează sufletește din chingile absurdului lumesc. Volumele Refluxul sensurilor, Patria mea A4 și Orologiul fără ore ajung să denunțe mecanica absurdă a lumii contemporane, mercantilismul și suficiența semenilor poetului. Incongruența poetului cu acest univers devine manifestă. Denunțând răul, trebuie să învețe să se delimiteze de el.

Irina Petraș relevă simplitatea și directețea acestor poeme care „își pierd acutele și foșnesc mătăsos tocmai fiindcă omenescul cu fețele sale destinale uimește încă." 219

Evaziunea este deseori eufemizată, în poeziile Anei Blandiana, fie prin simbolismul tanatic, fie prin variațiile descensus-ului (coborârea, alunecarea), fie prin dinamica mitică a intimismului, prin oniric sau prin schemele ascendente.

În cele ce urmează, vom analiza mai îndeaproape aceste varietăți ale evaziunii poetice blandiene.

\section{Variațiile descensus-ului}

\section{II.1. Schema simbolică a coborârii}

O fațetă insolită a evadării din contingent asociază această mecanică ontică redundantă, în viziunea poetică a Anei Blandiana, cu schema coborârii, cu un descensus, o cufundare molcomă în materia chtoniană:

„Această transparență a țărânii/ Pe care abia o ating cu pasul [...]/

Ce minunate priveliști ascunse/ Simte nevoia să îmi arate țărâna,/ În timp ce mă privește voluptuos/ Coborând." 220

Într-un alt text din volumul Refluxul sensurilor, mlaștini, apare aceeași eufemizare a evaziunii prin descensus, sub forma iluziei cufundării în metaforica „mlaștină de argint” a oglinzii ${ }^{221}$. Finalul textului, cu forma verbală

acestei bipolarități. Credința și necredința, îngerii și fiarele, binele și răul, dulcele și amarul se topesc în poeme luminoase totuși."

${ }^{219}$ Irina Petraș, art. cit., p. 1.

220 Ana Blandiana, Refluxul sensurilor, Ed. Humanitas, București, 2008, p. 73.

${ }^{221}$ Ibidem., p. 79: „Și te scufunzi în mlaștinile de argint/ și mint,/ și mint...” 
redundantă „,a minți”, ilustrează capcana existențială a simbolului spectacular (oglinda).

\section{II.2. Fațetele intimismului}

O modalitate de evadare în sfera intimismului este reflectată în izomorfismul apă-mormânt. Reveria eminesciană a poetei transformă infinitul oceanic în leagăn tanatic al desprinderii line de angoasa devenirii. De aceea, putem spune că forma supremă a fantasmelor evaziunii, în lirica Anei Blandiana, este trecerea în etern, dematerializarea: „O, lasă-mi leșu-ntins pe plaja/ Sfârșitului, ca să rămân/ Martor de-apoi nehotărârii-ți,/ Leagăn etern, ocean bătrân!". ${ }^{222}$

\section{II.3. Complexul umbrei}

Complexul umbrei este, în textul Blandianei, reziduul ontic al înlănțuirii de teluric, de mundan, expresia nevoii de eliberare sufletească, exprimată prin fugă, motiv literar ilustrativ pentru evaziunea blandiană.

Toposul acestei eliberări de mundan sunt „colinele”, spațiu paradiziac prin excelență, univers compensativ în care eul poetei se regăsește pe sine: „Afară pe coline sufletul/ Își regăsește respirația,/ Verdele ierbii îi face bine,/ Rostogolit prin otava/ Jumătate iarbă, jumătate mireasmă./ Respiră adânc, inspiră, expiră/ Primăvara care trece prin el/ Curățindu-l de spaime". ${ }^{223}$

Natura, cu iarba, otava și primăvara însăși (anotimp regenerator, al reînvierii regnurilor) sunt agenții exorcizării sufletești, ai purificării, în lumina cărora moartea însăși se metamorfozează într-o dimensiune fastă care-i conferă materiei chtoniene atributele intimiste ale unui refugiu compensativ în care eul poetei se regăsește pe sine: „În timp ce sufletul/ Se obișnuiește cu pământul/ Și respiră adânc". ${ }^{224}$

Aceeași perspectivă a toposului securizant, autarhic în senina și idilica desprindere de timp și de concret, regăseam într-unul dintre poemele în proză din volumul Cea mai frumoasă dintre lumile posibile, Dealuri, în care asociază imaginea mitizată a poetului Mihai Eminescu și cadrul edenic al Ipoteștilor:

"Dar când am descoperit perspectiva aceea neînchipuit de blândă, cu orizonturi rotunde, repetate ca într-un canon, deschiderea aceea neînchipuit de largă, asemenea unei catedrale desfășurate, înclinat și muzical, între zările nehotărâte încă să bareze privirea,

\footnotetext{
222 Ibidem., p. 47.

${ }^{223}$ Ana Blandiana, Patria mea A4, Ed. Humanitas, București, 2010, p. 27.

224 Idem.
} 
îngânându-se între ele moale, fără decizia vreunui unghi, am înțeles că între Eminescu și dealurile Ipoteștilor legătura este mai misterioasă și mai definitivă decât putusem bănui". 225

Complexul umbrei apare, în Vânătoare în timp (vol. Patria mea A4), în corelație cu motivul literar propriu temei evaziunii, la Ana Blandiana, menționat deja, anume, fuga: „Știu că salvarea e exclusă, dar/ Nu știu ce-ar însemna salvarea./ De-ncerc să fug, umbra și ea se mută,/ Mulându-se pe orizontul meu ca norii,/ Feroce și aproape protectoare-n grija/ De-a nu mă pierde, pradă altcuiva".226

Ferocitatea „umbrei” face o trimitre clară la Carl Gustav Jung și la modul cum acesta definea umbra, ca element constituent și inerent psihismului uman:

„În vise, umbra are tendința să apară sub forma unui personaj sinistru sau amenințător, [...]. De regulă are cev străin sau ostil, care stârnește un simțământ puternic de dezgust, mânie ori teamă. Iată de ce Jung s-a simțit îndreptățit să considere umbra un complex - adică un conglomerat de trăsături legate laolaltă prin afecte comune - care, asemenea tuturor complexelor posedă un miez arhetipal, în cazul de față arhetipul Dușmanului, Jefuitorului sau Străinului-celui-rău". ${ }^{227}$

\section{Evaziunea temporală}

Evaziunea temporală se metamorfozează, în Linia, într-o tentație a consumării gratuite, aproape ludice a interstițiilor acestuia: secundele, minutele, orele, zilele sau săptămânile:

„Doamne, ce risipă!/ Cum aruncam cu secundele, cu minutele,/ Cu orele, cu zilele, cu săptămânile, cu anii!/ Trecătorii se îngrămădeau să le prindă din aer,/ Nu le venea să creadă,/ Prietenii încercau să mă oprească,/ Dușmanii spuneau:/ Are ea vreun motiv, vreun câștig,/ Nu e nimeni atât de nebun.../ Dar eu eram,/ Eu continuam să risipesc ștergând/ Linia care desparte/ Sublimul de ridicol". ${ }^{228}$

Ieșirea din timp, din durată are drept cadru poetic o noapte copleșită de fiorul apocatastazei sensului. Apare, în aceste versuri din textul e noaptea, izomorfismul contrastant vizual, dar congruent semantic, întuneric - simbolism

225 Ana Blandiana, Cea mai frumoasă dintre lumile posibile, Ed. Cartea Românească, București, 1978, p. 63.

226 Ana Blandiana, op. cit., p. 21.

227 Anthony Stevens, Jung, Ed. Humanitas, București, 1996, p. 75.

228 Ana Blandiana, Refluxul sensurilor, Ed. Humanitas, București, 2008, p. 29. 
ignic: „E noaptea în care clopotnițele iau foc/ De la dangătul clopotelor/ Fluturând ca niște mari flăcări când pier./ Glorie, glorie care se-ncheie,/ Sunet și vuiet, scânteie/ Și capăt,/ Lumină lină ce se consumă/ Și se face scrum./ Pe pământ și în cer/ E noaptea-soroc/ În care totul se ia de la capăt:/ Du-mă/ Acum". ${ }^{229}$

Evaziunea supremă este eliberarea de lume prin solitudinea desăvârșită, pe care Blandiana o cere, într-o inedită rugă poetică, Demiurgului însuși: „O, Doamne, dezleagă-mă, dezleagă-mă/ De timp, de loc, de strămoși, de nepoți/ De toate și de toți,/ Și de mine însămi, de poți!/ Lasă-mă liberă, singură ca niciodată,/ Numai față de pagina mea vinovată". ${ }^{230}$

Textul se încheie într-o notă de ars poetica, prin care Blandiana acceptă o singură povară și anume cea a harului creator. Cealaltă povară, cea a lumii înseși, marcată plastic printr-o comparație în cheie vizuală, este un lest ontic de care poeta se vrea scăpată: „Să pot să plec fără să trag după mine/ Lumea ca peo față de masă/ cu farfurii și pahare/ Sparte de-a valma, amestecate cu vin și mâncare". ${ }^{231}$

IV. Hypnos - Oneiros

Regimul hipnotic din adorm (vol. Refluxul sensurilor) echivalează cu o înspăimântată refugiere telescopată în „somnul din somn”, ca formă de evadare dintr-un Real ale cărui vicisitudini poeta nu le mai suportă: „,Când nu mai pot să îndur/ Adorm/ Și, dacă-n somn se-aude/ Încă surd realitatea,/ Adorm în somn/ Trăgând speriată cu urechea/ Și, dacă și acolo mă ajunge,/ Adorm în somnul din somn". 232

Somnul reduplicat alunecă simbolic într-un intimism sepulcral, văzut ca unică soluție de exorcizare a eului de maladia gravă a Realului: „Și acolo,/ În mormântul de gradul trei/ Al neexistenței,/ Aștept cuminte/ Să mă trezesc vindecată/ În somnul al treilea,/ În somnul al doilea,/ În somnul prim..." 233

Antiteza somn - veghe relevă, în mandala (vol. Refluxul sensurilor), contrastul între ambiguitatea aproape dureroasă a Realului și purificarea, iluminarea trecerii în subconștient, acolo unde spiritul se hrănește din sine, întro combustie autarhică:

\footnotetext{
${ }^{229}$ Ibidem., p. 126.

${ }^{230}$ Ibidem., p. 101.

${ }^{231}$ Idem.

232 Ibidem., p. 83.

233 Ibidem., p. 83.
} 
„Imaginea intensă a diamantului ajutându-mă/ Să trec din confuza stare de veghe/ În brusca iluminare a somnului,/ Strălucire interioară [...]/ Încât nu se mai distinge/ Decât o misterioasă combustie/ Care semnifică totul./ Așa cum raza albă a diamantului/ Se face țăndări colorate,/ Așa cum șarpele își înghite coada/ Și devine inel,/ În adâncul rădăcinilor fără sfârșit/ Popoarele lumii delirează la fel". 234

Poeta încarcă mitic mesajul textului, amintind fie de Ouroboros, fie de teoria junghiană a inconștientului colectiv.

Ouroboros, în versurile Anei Blandiana, dincolo de ideea ciclicității și de tema eternei reîntoarceri, suscită o interpretare legată de corespondența teluric celest și de trecerea la un nivel superior de existență, cu alte cuvinte o îmbogățire spirituală, pe fondul dorinței dematerializării eului:

„„... șarpele care-și mușcă propria coadă, formând un cerc, rupe cu o evoluție lineară, marchează o astfel de schimbare încât pare a reapărea la nivelul unei ființe superioare, la nivelul ființei cerești sau spiritualizate, simbolizate de cerc $[. .$.$] ; dar această interpretare ascendentă nu se sprijină decât pe simbolica$ cercului, figură de o perfecțiune cerească". 235

Celălalt nivel de interpretare a constelației simbolice a șarpelui care-și mușcă propria coadă se regăsește într-un alt poem din Refluxul sensurilor, in memoriam: „Eternitatea rotunjită cu greu a șarpelui/ Care-și înghite coada și se hrănește pe sine,/ Fluviul etern suindu-și apele spre izvoare/ Ca să curgă din nou de cealaltă parte,/ Întuneric rotund dincolo de drumul/ Zilnic al soarelui/ Care intră și iese din moarte". ${ }^{236}$

Vorbim, aici, despre capcana ontică a ciclului morții și reînvierii, veșnica reîntoarcere, vegheată de motivul tanatic:

„Dimpotrivă, șarpele mușcându-și coada, și care nu încetează să se învârtă pe el însuși, se închide în propriul lui ciclu [...], parcă osândit pe vecie să nu poată scăpa din ciclul său pentru a se ridica la un nivel superior: simbolizează atunci veșnica reîntoarcere, cercul nesfârșit al renașterilor, veșnica repetiție, care trădează predominanța unei pulsiuni fundamentale de moarte". ${ }^{237}$

234 Ibidem., p. 131.

${ }^{235}$ Jean Chevalier, Alain Gheerbrant, Dicționar de simboluri, vol. III, Ed. Artemis, București, 1995, p. 416.

236 Ana Blandiana, op. cit., p. 133.

${ }^{237}$ Jean Chevalier, Alain Gheerbrant, op. cit., p. 416. 
Unul dintre poemele „în scapăt” 238 ale Anei Blandiana, Ș.a.m.d. (vol. Orologiul fără ore) ridică oniricul la rangul de formă evazionistă privilegiată. Poeta imaginează chiar oniricul într-o ipostază ludică și-ntr-o perpetuă telescopare a visului încasetat, caracteristică structurilor poetice ale evaziunii din creația sa: „Ce joc minunat de-a mine însămi!/ Ce joc fără sfârșit!/ Pentru că sfârșitul/ Va fi și el visat tot de mine/ Și așa mai departe..." 239

\section{Imposibilitatea evaziunii}

Există, în aceeași proporție cu tentația evaziunii, la Ana Blandiana, și oroarea de limită ca și oroarea de vid, de haos. Aceasta generează spaima de claustrare în închisoarea propriului trup. De aici, imposibilitatea evaziunii: „Clipa dintre lumina fulgerului/ Și corpul lui asurzitor,/ [...] Mă ține întinsă/ Pe un pat de tortură/ Între încăperea de carne obscură/ Și lumina de-apoi/ Ce spaimă firească:/ Nu pot să mai merg înainte/ Nu pot să mă-ntorc înapoi". ${ }^{240}$

Cureaua rucsacului (vol. Patria mea A4) dezvăluie aceeași neliniște, insecuritate, stârnite de imposibilitatea evadării. Poeta îmbină, aici, motivul retragerii cu cel desacralizant angelic, tocmai pentru a sugera aceeași spaimă de limită, coroborată cu ideea de solitudine în mijlocul mulțimii aneantizatoare spiritual: „Singurătatea ia forma aglomerărilor,/ Mulțimile sunt pustiuri,/ Retragerea înspre culmi cu povara/ De tăceri isihaste e tot mai nesigură,/ În timp ce pe marginea omoplaților/ Cureaua rucsacului/ Roade cioturile cu rămășițe de pene". ${ }^{241}$

Imaginea îngerului estropiat este emblematică pentru tabloul terifiant al însingurării eului în mijlocul mulțimii ce depersonalizează.

În poezia Chihlimbar întâlnim cealaltă fațetă a motivului solitudinii, anume cea fastă. Blandiana își asumă însingurarea în ipostaza ei creatoare, devenită balsam sufletesc, o cale vindecătoare spiritual. Interesantă este, în aceste versuri, constelarea dimensiunii mitice a solitudinii de mitemul claustrării, care nu mai duce la spaima claustromorfă trezită de imaginea mormântului: „Uitând de lume și uitând de mine,/ Simt cum singurătatea mă

${ }^{238}$ Irina Petraș, art. cit., p. 2.: „Cu trupul în scapăt, în jocul alterilor, pe care visul îl face posibil, poeta exersează întrupări sfidând fragilitatea eului integrat de la lumina zilei."

239 Ana Blandiana, Orologiul fără ore, Ed. Humanitas, București, 2016, p. 11.

${ }^{240}$ Ana Blandiana, Patria mea A4, Ed. Humanitas, București, 2010, p. 41.

${ }^{241}$ Ibid., p. 45. 
umple ca o miere/ Curgând în vasul ce i se cuvine/ Pentru c-o soarbe și o cere// [...] Dar voluptate-i chinul, nu calvar/ Și îmi aduc de mine-aminte/ Ca de-o gâză prinsă-n chihlimbar,/ În cripta luminoasă de cuvinte". ${ }^{242}$

Epitetul cu nuanță oximoronică „cripta luminoasă”, extins apoi în construcția metaforică „cripta luminoasă de cuvinte", definește sugestiv evaziunea în sfera securizantă a creației la care aspiră poeta.

Pentru Blandiana, maladia copleșitoare este timpul însuși, durata care ne marchează definitiv și irevocabil existența. Tocmai de aceea, poezia Boala îmbină lirismul cu terminologia din sfera medicală. Așadar, lexeme precum „virus", "epidemie”, ,"morb” definesc universul în care poeta se-ntreabă retoric dacă este posibilă retragerea din calea acestei epidemii molipsitoare: „Să fie doar o boală molipsitoare?/ Timpul să fie un virus/Care trece de la bolnav la bolnav/ Și lasă urme adânci în carnea pe care-o atinge?/ Ar fi posibil să te retragi din calea epidemiei/ Și morbul să nu-ți pătrundă în sânge?". ${ }^{243}$

Aceeași certitudine a prizonieratului ontic perpetuu, care presupune, implicit, imposibilitatea evaziunii, reapare în textul Într-o rană: „Trăim într-o rană/ Fără să știm/ Al cui este trupul rănit,/ Nici de ce./ Singura certitudine este durerea/ Care ne înconjoară". ${ }^{244}$

Anonimitatea și certitudinea sunt coordonatele unei angoase existențiale ce hrănește, la nivelul discursului liric, tonalitatea ușor angoasantă, marcată și de punctele de suspensie din final. Neputința de-a vindeca și, mai mult, infestarea cu propria prezență sunt semnele unui univers absurd în care Eul se simte iremediabil pierdut.

Constatăm, în viziunea despre lume a poetei Ana Blandiana, două tipuri de solitudine: una, asumată și căutată adesea cu încrâncenare, este singurătatea creatoare, formă de ataraxie care purifică spiritual; cealaltă este singurătatea în aglomerare, în mulțime, acea în-lumire nefastă care înspăimântă, pentru că este un consum de energie personală inutil și nefiresc: „Ceea ce mă înspăimântă/ E singurătatea-n mulțime,/ Aglomerările rele/ De ființe necunoscute-ntre ele/ Și mai neînsemnate/ Și mai fără chip/ Decât firele de nisip/ Care formează-un pustiu,/ Decât picăturile/ Care formează o mare". 245

În genere, mulțimile depersonalizează, demoralizează și atacă însăși ființa poetei, ce se simte prinsă-n capcana acestei alcătuiri umane absurde.

\footnotetext{
242 Ibidem., p. 47.

${ }^{243}$ Ana Blandiana, Orologiul fără ore, Ed. Humanitas, București, 2016, p. 27.

${ }^{244}$ Ibid., p. 31.

245 Ibid., p. 81.
} 
Blandiana pare să transmită prin versurile sale că, odată ce-ai fost prins în magma permanent mișcătoare a mulțimii, nu mai poți scăpa din haosul ei niciodată: „Minuscule fiare/ Strânse în haite/ De ființe străine,/ Indiferente unele altora/ Și fiecare față de sine". ${ }^{246}$

\section{BIBLIOGRAFIE}

Antofi, Simona, General Dictionary of Romanian Literature - Obverse and Reverse Critical Reception, în Oana Cenac (coord., edit.), International Conference of Common Vocabulary/Specialized Vocabulary: Manifestations of Creativity of Human Language, 6-7 iunie 2014, publicate în volumul MANIFESTARI ALE CREATIVITATII LIMBAJULUI UMAN, 2014, p. 13-19, ISBN:978-606-17-0623-5, Accession Number WOS:000378446400001

Blandiana, Ana, Refluxul sensurilor, Ed. Humanitas, București, 2008.

Blandiana, Ana, Patria mea A4, Ed. Humanitas, București, 2010.

Blandiana, Ana, Orologiul fără ore, Ed. Humanitas, București, 2016.

Blandiana, Ana, Cea mai frumoasă dintre lumile posibile, Ed. Cartea Românească, București, 1978.

Cenac Oana, General aspects of current political terminology, în Lexic politic - discurs politic, 2014, p.124-130, ISBN:978-606-17-0633-4, WOS: 000378358200007.

Chevalier, Jean, Gheebrant, Alain, Dicționar de simboluri, vol. III, Ed. Artemis, București, 1995.

Nicoleta Ifrim, Theoretical Aspects of Identity Discourse in Post-totalitarian Cultures, în Procedia-Social and Behavioral Journal (ISSN: 1877-0428) (ISSN: 1877-0509), vol.63/2012 ELSEVIER, pp.35-40, DOI 10.1016/j.sbspro.2012.10.007, http://www.sciencedirect.com/science/journal/18770428/63/supp/C,WOS:000361 477200006.

Stevens, Anthony, Jung, Ed. Humanitas, București, 1996.

Patriche, Monica, Credința ca unica șansă în viziunea poetei Ana Blandiana, în rev. „Ziarul Lumina”, 4 nov. 2016.

Petraș, Irina, Eroziuni secundare, în rev. „Viața Românească”, București, nr. 9/ 2016.

${ }^{246}$ Idem., p. 31. 